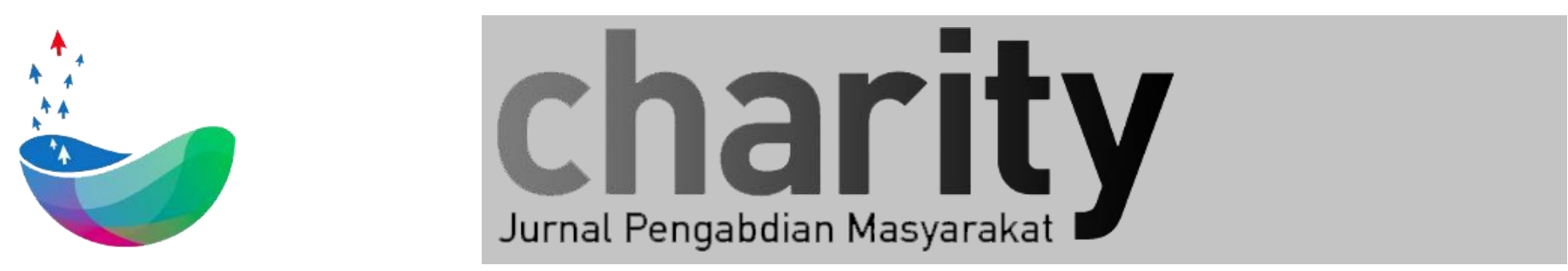

\title{
Pelatihan Aplikasi Power Point sebagai Media Pembelajaran Jarak Jauh di Pondok Pesantren Assubkiyah
}

\author{
Mohamad Tohir ${ }^{1}$, Aisyi Syafikarani ${ }^{2}$, Adya Mulya Prajana ${ }^{3}$, Raihan Nagar Rinaldi ${ }^{4}$, Fianisya Rana Pelangi ${ }^{5}$, Ceka Elgy \\ Dwi Putra ${ }^{6}$
}

${ }^{1}$ Desain Komunikasi Visual, Fakultas Industri Kreatif, Telkom University

${ }^{2}$ Desain Komunikasi Visual, Fakultas Industri Kreatif, Telkom University

${ }^{3}$ Desain Komunikasi Visual, Fakultas Industri Kreatif, Telkom University

${ }^{4}$ Desain Komunikasi Visual, Fakultas Industri Kreatif, Telkom University

${ }^{5}$ Desain Komunikasi Visual, Fakultas Industri Kreatif, Telkom University

*mt.fauzy@gmail.com, aisyisyafikarani@telkomuniversity.ac.id, adyaprajana@telkomuniversity.ac.id

\section{INFO ARTIKEL}

Diterima 03 Februari 2021

Direvisi 04 Februari 2021

Disetujui 28 Agustus 2021

Tersedia Online 31 Agustus 2021

\begin{abstract}
ABSTRAK
Pelatihan ini merupakan kegiatan para pengajar dan mahasiwa Program Studi Desain Komunikasi Visual - Fakutas Industri Kreatif Universitas Telkom dalam membantu mengembangkan keahlian terkait profesi para guru di Pondok Pesantren Assubkiyah dengan tema "Pelatihan Aplikasi Power Point Sebagai Media Pembelajaran Jarak Jauh di Pondok Pesantren Assubkiyah". Kegiatan ini bertujuan untuk : 1) Memberikan sumbangsih keilmuan khususnya program studi Desain Komunikasi Visual untuk masyarakat umum; 2) Mengembangkan keahlian terkait profesi guru/tenaga pengajar di Pondok Pesantren Assubkiyah; 3) Memberikan bekal ketrampilan; serta 4) Memberikan kesempatan para guru dan pengurus pondok pesantren untuk menimba/menambah ilmu yang tidak diajarkan dilingkungan sekolahnya. Diharapkan setelah program ini berlangsung, para pengajar dan pengurus Pondok Pesantren Assubkiyah dapat menambah ketrampilan mereka sehingga kegiatan belajar mengajar dapat berlangsung dengan lebih baik.
\end{abstract}

Keyword: pelatihan, power point, pesantren.

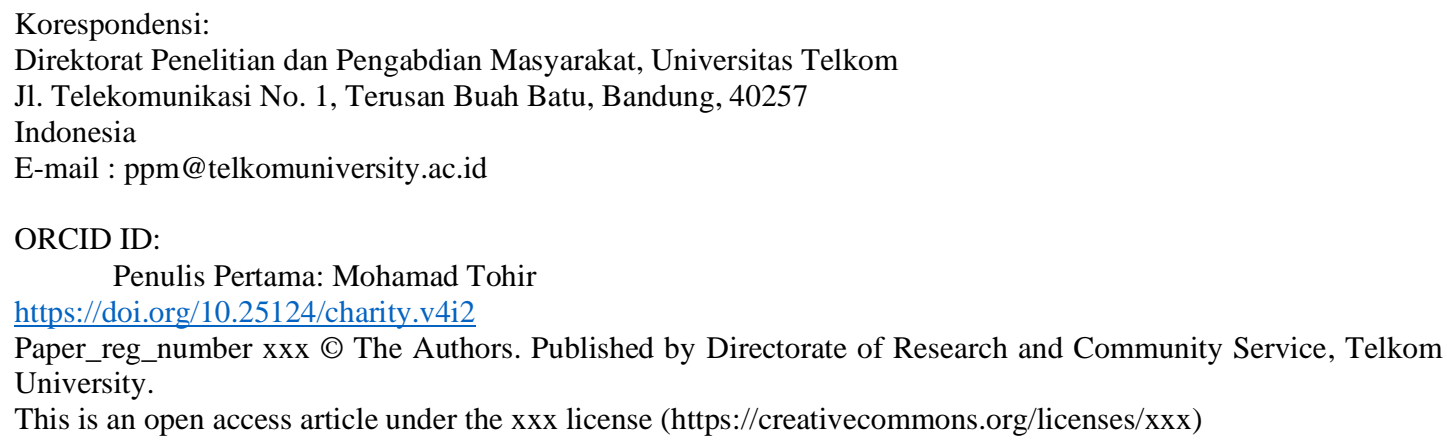




\section{Pendahuluan}

Pondok Pesantren Assubkiyah adalah sebuah lembaga pendidikan Islam yang berlokasi di Kp. Sodong, Ds. Nagrak, Kec. Cangkuang, Kab. Bandung. Merupakan lembaga pendidikan tradisional yang hingga saat ini masih berjalan dan berkembang. Tidak jarang para orang tua yang beragama Islam mengarahkan anak-anaknya untuk mengikuti pendidikan di pesantren, mulai dari anak sekolah dasar hingga sekolah menengah atas. Salah satunya adalah di Pondok Pesantren Assubkiyah. Pondok pesantren tersebut menyelenggarakan pendidikan madrasah tsanawiyah (setingkat SMP), dan madrasah aliyah (setingkat SMA).

Pada masa pandemi Covid 19 dan pemberlakuan PSBB di wilyah Jawa Barat, proses pembelajaran di Pondok Pesantren Assubkiyah mengalami kendala dikarenakan para pengajar yang berdomisili diluar Pondok Pesantren Assubkiyah tidak dapat dengan bebas keluar masuk kampus akibat kekhawatiran penyebaran virus, hal lain yang menjadi permasalahan adalah kebiasaan proses pembelajaran yang dilakukan secara konvensional dengan menggunakan papan tulis. Pada tahun ajaran baru, lembaga ini menerima santri dan peserta didik baru, dengan harapan dapat menghasilkan lulusan yang berkualitas, pesantren ini juga terus mengembangkan program pembelajaran dan fasilitas sekolah.

Saat ini, penggunaan komputer dalam kegiatan akademis di lingkungan Pondok Pesantren Assubkiyah belum dapat diterapkan secara maksimal, Inisiasi dari program itu sendiri telah dimulai, ditandai dengan penyediaan fasilitas komputer oleh pihak sekolah namun masih terbatas, terutama hanya memiliki sebuah projector saja, dilain pihak keterbatasan kompetensi tenaga pendidik juga masih menjadi kendala. Seorang pendidik memerlukan media pembelajaran yaitu alat yang dapat membantu proses belajar mengajar sehingga makna pesan yang disampaikan menjadi lebih jelas dan tujuan pendidikan atau pembelajaran dapat tercapai dengan efektif dan efisien [3].

Atas dasar hal tersebut di atas, maka peningkatan kompetensi untuk mencapai pembelajaran yang efektif dan efisien melalui pelatihan penggunaan komputer bagi tenaga pendidik di lingkungan Pondok Pesantren Assubkiyah menjadi satu potensi pemberian nilai lebih bagi proses belajar mengajar maupun dalam kegiatan administratif.

Melihat kondisi di lapangan, pondok pesantren ini memiliki potensi untuk berkembang, setiap tahun ajaran baru selalu menerima murid tidak kurang dua kelas, fasilitas bangunan yang terus diperbaiki atau ditambah sesuai kebutuhan, juga adanya rencana pengembangan kurikulum dan sumberdaya manusia. 


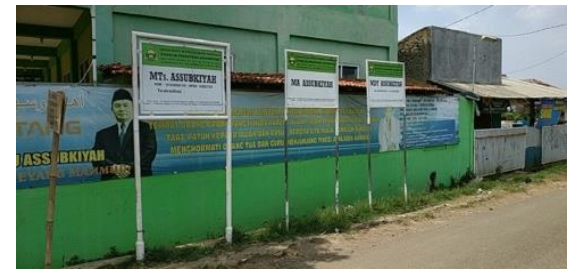

(a)

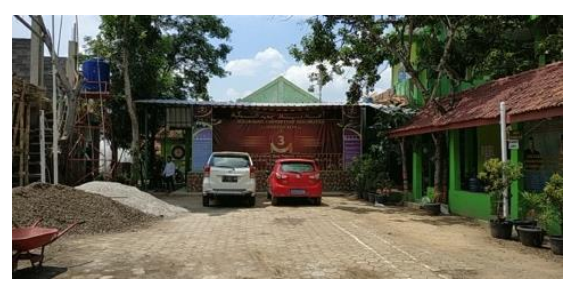

(c)

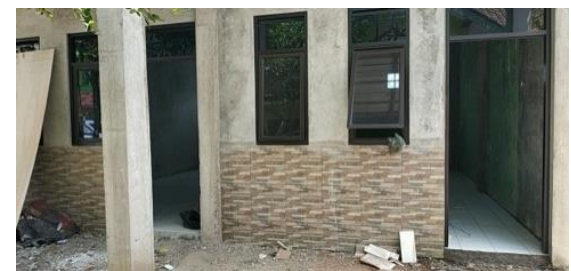

(b)

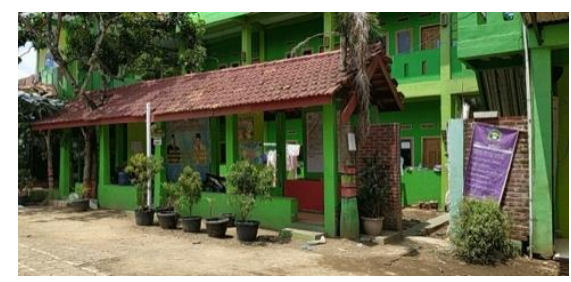

(d)

Gambar 1.2 Foto kondisi terkini Pondok Assubkiyah, Tampak depan (a), Ruang kelas(b), Tampak Depan Parkiran(c) dan Tampak Samping Parkiran(d)

\section{Solusi Pengabdian yang Ditawarkan}

Keterbatasan kompetensi tenaga pendidik, khususnya pada kegiatan pembelajaran dalam jaringan pada masa PSBB ini menjadi salah satu kendala dalam pengembangan program pendidikan di Pondok Pesantren Assubkiyah, maka peningkatan kompetensi melalui Pelatihan Aplikasi Power Point Sebagai Media Pembelajaran Jarak Jauh di Pondok Pesantren Assubkiyah bagi tenaga pendidik di lingkungan Pondok Pesantren Assubkiyah menjadi satu potensi pemberian nilai lebih bagi proses belajar mengajar jarak jauh. Power Point adalah paket program yang digunakan untuk membantu pembuatan bahan bagi keperluan presentasi [5]

Pentingnya pelatihan penguasaan aplikasi Power Point dan manfaatnya bagi proses pembelajaran terutama untuk meningkatkan kompetensi guru dapat diketahui melalui jurnal-jurnal kegiatan pengabdian kepada masyarakat sebelumnya. Seperti jurnal dengan judul "Perangkat Lunak Power Point untuk Meningkatkan Kinerja Guru di SD dan SMP 19 Muhammadiyah Sawangan Depok". Kesimpulan dari kegiatan tersebut adalah bahwa masih perlunya sosialisasi dan pelatihan secara berjenjang kepada para guru tentang penguasaan Power Point sebagai pembuatan bahan ajar yang menarik bagi siswa [4]

Untuk mengatasi permasalahan yang dihadapi seperti tersebut di atas, maka akan diadakan Pelatihan Aplikasi Power Point Sebagai Media Pembelajaran Jarak Jauh di Pondok Pesantren Assubkiyah sebagai upaya peningkatan kompetensi bagi tenaga pengajar di Pondok Pesantren Assubkiyah dalam melaksanakan kegiatan pembelajaran jarak jauh. 
Pada program pengabdian masyarakat ini target luarannya adalah:

- Pelatihan Aplikasi Power Point Sebagai Media Pembelajaran Jarak Jauh di Pondok Pesantren Assubkiyah.

- Publikasi ilmiah atau popular.

\section{Metode Pelatihan}

Pengabdian masyarakat dilaksanakan dalam bentuk pelatihan penggunaan aplikasi power point. Kegiatan ini akan dilaksanakan sebagai solusi yang ditawarkan untuk mengatasi permasalahan dan/atau untuk meningkatkan kompetensi para guru. Pelatihan ini dilaksanakan pada :

Tanggal : 13 Oktober 2020

Pukul : 09.00 WIB - Selesai

Lokasi : Pondok Pesantren Assubkiyah

Kp. Sodong, Ds. Nagrak, Kec. Cangkuang, Kab. Bandung.

Materi pada pelatihan ini disampaikan secara tatap muka, serta dipraktekkan secara langsung oleh peserta pelatihan, diharapkan dengan metode ini pelatihan yang disampaikan dapat dengan mudah dipahami. Pendekatan desain komunikasi visual digunakan untuk dapat mempermudah proses pelatihan yaitu, memecahkan masalah dengan berpikir gambar maupun teks, guna menyampaikan pesan verbal, pesan visual maupun pesan verbal dan visual [5].

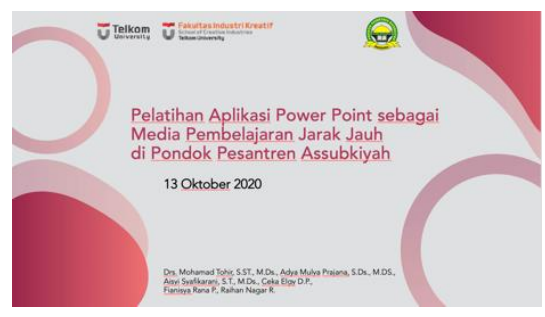

(a)

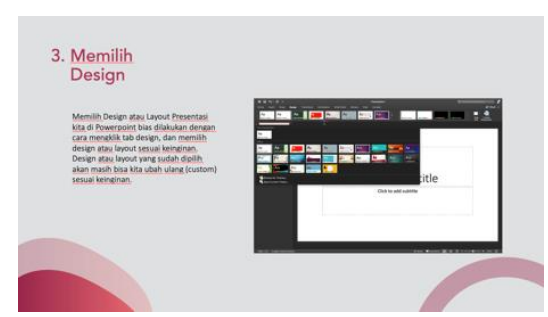

(c)

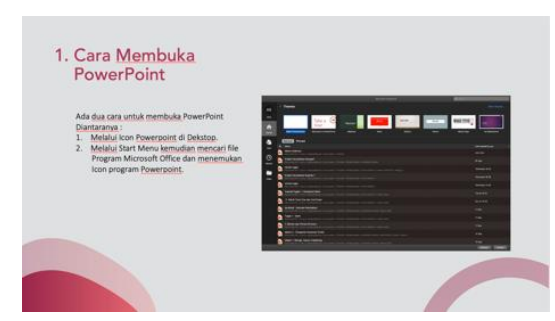

(b)

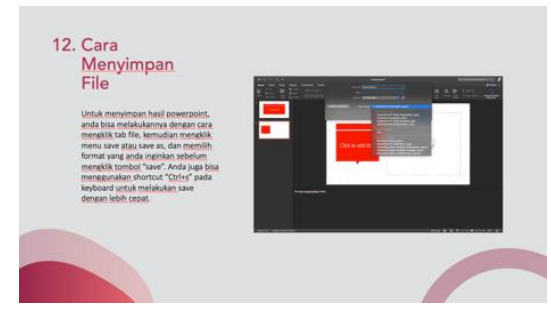

(d)

Gambar 1.3 Materi pelatihan Slide Pembuka (a), Cara Membuka Power Point (b), Memilih Design (c), dan Cara Menyimpan File(d)

Selain memberikan materi secara langsung, materi pelatihan ini juga dikemas dalam bentuk video tutorial. Dalam buku Multimedia Konsep dan Aplikasi dalam PendidikanDijelaskan bahwa kelebihan media video dalam sebuah proses pembelajaran pengguna dapat melakukan pengulangan (replay) pada bagian-bagian tertentu untuk melihat gambaran yang lebih 
fokus. Sehingga dengan video tersebut materi pelatihan mengenai aplikasi Power Point dapat dengan mudah dipelajari kembali dilain waktu [1].

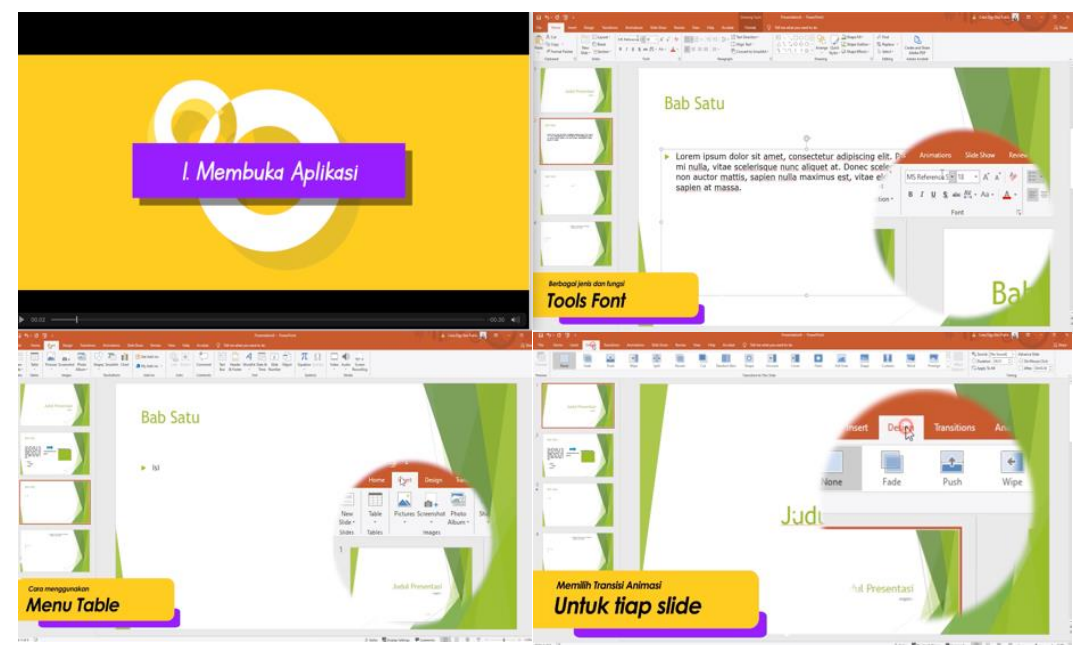

Gambar 1.4 Materi pelatihan dalam bentuk video tutorial

Agar memudahkan para guru untuk mempelajari kembali, Materi video tutorial Power Point dibagi menjadi 7 tahapan video. 1) Membuka aplikasi Power Point, 2) Membuat Slide baru dan penjelasan mengenai layout Slide, 3) Penjelasan Tools di tab Home, 4) Penjelasan Insert Tools, 5) Transisi dan membuat animasi teks. 6) Bagaimana membuat Slide Show, 7) Bagaimana menyimpan data.

Program pengabdian masyarakat ini ditekankan pada peningkatan kompetensi tenaga pendidik dalam kegiatan penggunaan/penguasaan teknologi komputer. Pelaksanaan kegiatan pelatihan ini melibatkan tenaga pengajar (dosen) dan mahasiswa dari Program Studi Desain Komunikasi Visual, Fakultas Industri Kreatif, Universitas Telkom. Pelaksanaan kegiatan ini direncanakan pada bulan Oktober 2020, berlokasi di Pondok Pesantren Assubkiyah, adapun tahapan pelaksanaan program tergambar dalam diagram di bawah ini: 


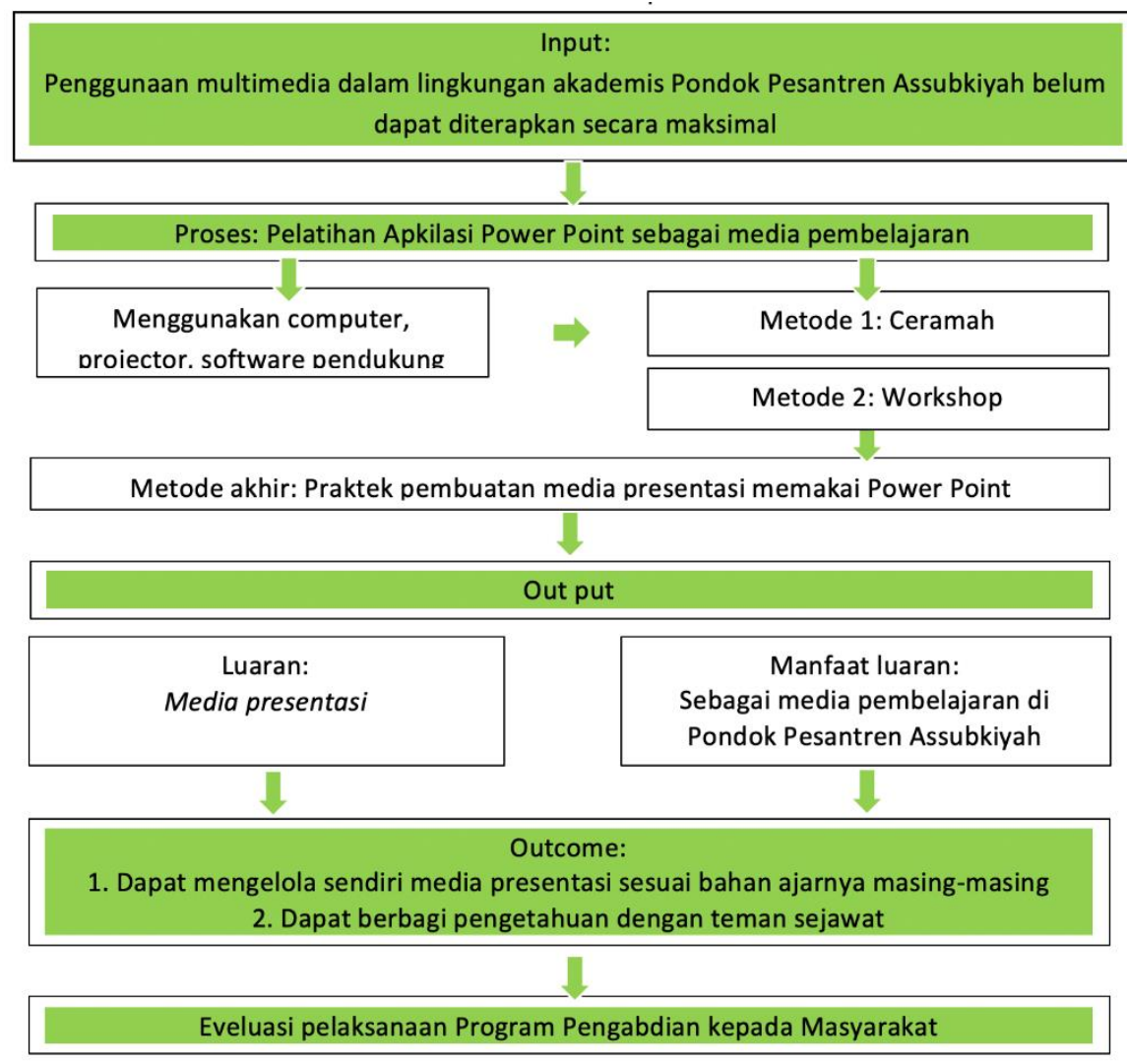

Gambar 1.5 Gambaran Iptek

Pelaksanaan pengabdian kepada masyarakat ini telah sesuai dengan roadmap yang dicanangkan oleh universitas, kegiatan dilakukan dengan skema regular dengan luaran wajib yang akan dipublikasikan dalam media popular dan luaran lain berupa produk/jasa pelatihan penggunaan computer sebagai media pembelajaran bagi para guru.

\section{Partisipasi Mitra dalam Pelaksanaan Program}

Program pengabdian masyarakat ini ditekankan pada peningkatan kompetensi tenaga pendidik dan administratif dalam kegiatan penggunaan teknologi multimedia, dengan melibatkan tenaga pendidik dan tenaga administratif, serta penyediaan tempat bagi pelaksanaan oleh pihak Pondok Pesantren Assubkiyah.

\section{Feedback dan Keberlanjutan Program}

Evaluasi dilakukan untuk melihat sejauh mana pencapaian pelaksanaan pelatihan, kendala yang dihadapi, beserta kemungkinan penanggulangannya. Selanjutnya dilakukan monitoring keberlanjutan penggunaan komputer dan multimedia sebagai media pembelajaran sehingga manfaatnya dapat dirasakan oleh guru dan murid.

Hasil yang dicapai, evaluasi \& feedback/masukan dari masyarakat sasar terhadap kegiatan pengabdian kepada masyarakat yang telah dilaksanakan 
telah dikumpulkan melalui survey kuesioner peserta PkM Universitas Telkom.

Dari kuesioner tersebut 20 dari 20 orang (100\%) menyatakan sangat setuju bahwa program pengabdian masyarakat ini sudah sesuai dengan tujuan kegiatan itu sendiri. Program pengabdian masyarakat ini sudah sesuai dengan kebutuhan masyarakat ditunjukan oleh sebanyak 20 orang (100\%) yang menyatakan sangat setuju akan hal tersebut. Sebanyak 15 orang atau $75 \%$ menyatakan sangat setuju waktu pelaksanaan program pengabdian masyarakat ini relatif telah mencukupi sesuai kebutuhan, sedangkan 5 orang (25\%) menyatakan setuju. 15 orang atau sebesar $75 \%$ menyatakan sangat setuju dengan dosen dan mahasiswa Universitas Telkom bersikap ramah, cepat dan tanggap membantu selama kegiatan, dan sisanya sebanyak 5 orang atau sebesar 25\% menyatakan setuju. Sebanyak 20 orang (100\%) menyatakan sangat setuju bahwa masyarakat setempat menerima dan mengharapkan program pengabdian masyarakat Universitas Telkom saat ini dan masa yang akan datang.

\section{Dokumentasi Foto Kegiatan}

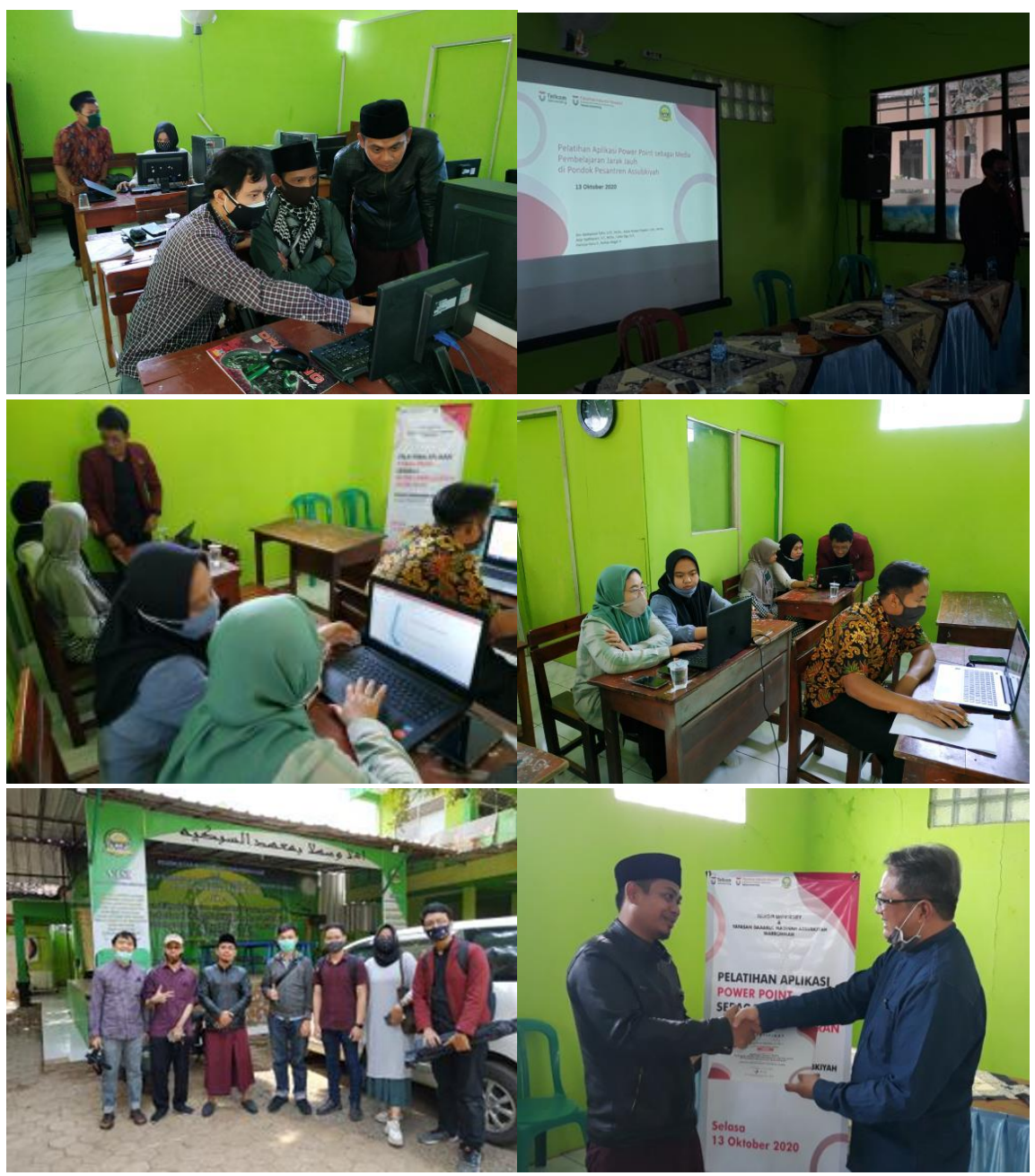

Gambar 1.7 Dokumentasi kegiatan 


\section{DAFTAR PUSTAKA}

[1] Munir, 2015, Multimedia Konsep dan Aplikasi dalam Pendidikan, Alfabeta, Bandung.

[2] Tinarbuko, Sumbo, 2015, Desain Komunikasi Visual, Penanda Zaman Masyarakat Global, CAPS, Yogyakarta.

[3] Nurrita, T. 2018. Pengembangan Media Pembelajaran Untuk Meningkatkan Hasil Belajar Siswa. Misykat, 3(1), 171-187. https://media.neliti.com/media/publications/271164- pengembanganmedia-pembelajaran-untuk-me- b2104bd7.pdf.

[4] Shedriko, Heri S. Setiawan, Kusmayadi, 2018. Perangkat Lunak Power Point untuk Meningkatkan Kinerja, Guru di SD dan SMP 19 Muhammadiyah Sawangan Depok, Jurnal PkM: p-ISSN 2614-574X, e-ISSN 2615-4749, hal 151-158.

[5] Taufik Iqbal, Rizaldi Akbar, 2020, Pelatihan Internet dan Power Point, untuk Guru-guru di SD Negeri 19 kota Sabang, Jurnal PkM: Bakti Buana https://ejurnal.stimi-bjm.ac.id/index.php/BBJM/ 